\title{
SPOTTED
}

\section{Spotted around the web: Gut issues, autism screens, prenatal genetic tests}

\author{
BY JILL ADAMS
}

7 JANUARY 2022 